\title{
PERAN PEKERJA SOSIAL DALAM PENANGANAN ANAK JALANAN
}

\author{
Oleh: \\ Fadilah Putri, Soni A. Nulhaqim, \& Eva Nuriyah Hidayat \\ Email: \\ fdlh11@gmail.com; soninulhakim@gmail.com; enuriyah@yahoo.com
}

\begin{abstract}
ABSTRAK
Anak jalanan adalah sebuah potret kehidupan yang berasal dari jalanan yang sangat rentan mengalami berbagai masalah yang ada pada masyarakat. Dari berbagai kemungkinan yang dapat menimpa anak jalanan seperti kekerasan, korban eksploitasi, seks bebas dan sebagainya, pemerintah melakukan upaya dalam menanggulangi anak jalanan dengan dibentuknya Program Kesejahteraan Sosial Anak (PKSA). Program ini menjadi prioritasi nasional Kementrian Sosial RI untuk mewujudkan pemenuhsn hsk dasar anak dan perlindungan. Melalui PKSA, diharapkan dapat meminimalisasi menjamurnya anak jalanan. Pelaksanaan Selain bantuan dana, PKSA juga memberikan pendamping yang dilakukan oleh tenaga professional yang disebut Sakti Peksos (Satuan Bakti Pekerja Sosial). Sakti Peksos ditempatkan di Rumah Perlindungan Anak yang menangani permasalahan anak.

Kata kunci: Peran Pekerja Sosial, Sakti Peksos,PKSA, Anak Jalanan
\end{abstract}

\section{PENDAHULUAN}

Dampak krisis ekonomi yang berkepanjangan adalahh meningkatnya jumlah penduduk miskin, baik diperkotaan maupun di perdesaan. Banyak keluarga yang tidak mampu memenuhi kebutuhan sosial dasar akibat meningkatnya berbagai harga kebutuhan pokok. Keadaan yang seperti inilah yang memaksa seluruh anggota keluarga untuk dapat membantu memperbaiki ekonomi keluarga dengan melibatkan seluruh anggota keluarga mencari nafkah, termasuk anak. Pelibatan anak-anak untuk membantu ekonomi keluarga inilah yang menyebabkan jalanan dikota-kota besar dipenuhi anak jalanan. Anak jalanan merupakan salah satu dari sekian banyak masalah yang sedang dihadapi oleh negara-negara berkembang, termasuk Indonesia. Anak jalanan adalah sebuah potret kehidupan yang berasal dari jalanan yang sangat rentan mengalami berbagai masalah yang ada pada masyarakat. Tidak sedikit dari anak jalanan ini terlibat masalah seperti kriminalitas, eksploitasi seks, perdagangan obat-obat terlarang, tertular virus HIV AIDS dan ban bahkan menjadi korban pembunuhan. Data BPS tahun 2012, jumlah anak jalanan di Indonesia mencapai angka 135.983 jiwa, dengan persebaran di DKI Jakarta sebagai berikut:

Tabel 1.1

Jumlah Anak Jalanan di DKI Jakarta

\begin{tabular}{|l|c|}
\hline \multicolumn{1}{|c|}{ Daerah } & Jumlah \\
\hline Kepulauan Seribu & - \\
\hline Jakarta Selatan & 142 \\
\hline Jakarta Timur & 890 \\
\hline Jakarta Pusat & 70 \\
\hline
\end{tabular}




\begin{tabular}{|c|c|} 
Jakarta Barat & 70 \\
\hline Jakarta Utara & 395 \\
\hline Total & $\mathbf{1 5 6 7}$ \\
\hline
\end{tabular}

Sumber : Data BPS Tahun 2012

Dari berbagai kerentanan yang dihadapi oleh anak jalanan menyebabkan mereka tidak dapat bebas mengakses sumber-sumber yang berpotensi untuk perkembangan hidupnya. Berdasarkan perjanjian internasional, Perserikatan Bangsa Bangsa (PBB) dalam konvensi hak-hak anak dikelompokkan menjadi 4 kategori, yaitu :

1. Hak kelangsungan hidup, hak untuk melestarikan dan mempertahankan hidup dan hak memperoleh standar kesehatan tertinggi dan perawatan yang sebaik-baiknya.

2. Hak perlindungan, perlindungan dari diskriminasi, eksploitasi, kekerasan dan ketelantaran.

3. Hak tumbuh kembang, hak memperoleh pendidikan dan hak mencapai standar hidup yang layak bagi perkembangan fisik, mental, spiritual, moral dan sosial.

4. Hak berpartisipasi, hak untuk menyatakan pendapat dalam segala hal yang mempengaruhi anak.

(http://bappeda.kendalkab.go.id/index.php?option=com_content\&view=article \& catid=29:pemsosbud\&id=87:konveksi-hak-hak-anak-kha)

Berdasarkan empat kategori yang dirumuskan PBB dalam konvensi hak-hak anak diatas sudah selayaknya anak jalanan mendapatkan hak yang sama dengan anak lainnya untuk mendapatkan hak kelangsungan hidup yang layak, perlindungan, tumbuh kembang dan hak berpartisipasi. Hal ini juga di sesuai dengan Undang Undang No. 23 Tahun 2002 Pasal 4 Tentang Perlindungan Anak menegaskan bahwa setiap anak berhak untuk dapat hidup, tumbuh, berkembang dan berpartisipasi secara wajar sesuai dengan harkat dan martabat kemanusiaan, serta mendapat perlindungan dari kekerasan dan diskriminasi.

Berbagai upaya penanggulangan masalah anak jalanan pun dilakukan, baik berupa program yang dicanangkan pemerintah maupun program dilakukan lembaga-lembaga sosial bersama masyarakat. Keberhasilan sebuah program tidak akan lepas dari kerjasama yang dilakukan seluruh stakeholder. Seperti yang tertuang dalam Undang-Undang Dasar 1945 Pasal 34 bahwa "fakir miskin dan anak terlantar dipelihara oleh negara". Itu berarti pemerintah, lembaga-lembaga sosial dan masyarakat mempunyai tanggung jawab menanggulangi anak terlantar, yang didalamnya termasuk anak jalanan.

Salah satu upaya yang dilakukan oleh pemerintah dalam menanggulangi anak jalanan adalah dibentuknya Program Kesejahteraan Sosial Anak (PKSA). Dimana program ini menjadi prioritas nasional Kementrian Sosial RI untuk mewujudkan pemenuhan hak dasar anak dan perlindungan anak dari pelantaran, eksploitasi dan diskriminasi sehingga tumbuh kembang, kelangsungan hidup dan partisipasi anak dapat terwujud. Sasaran dari PKSA adalah anak-anak yang membutuhkan perlindungan meliputi anak balita terlantar, anak terlantar, anak jalanan, anak berhadapan dengan hukum, anak dengan kecacatan dan anak yang memerlukan kebutuhan khusus. Dengan PKSA in pemerintah Dinas Sosial DKI Jakarta juga mencanangkan bahwa Jakarta akan bebas anak jalanan tahun 2014.

Melalui PKSA, Dinas Sosial DKI Jakarta meminimalisir menjamurnya anak jalanan dengan memperbanyak rumah singgah. Menurut Kepada Dinas Sosial Jakarta dalam berita elektronik di Merdeka.com, DKI Jakarta sudah mempunyai rumah singgah untuk anak jalanan. Rumah singgah berfungsi memberikan bekal keterampilan kepada anak jalanan sehingga nantinya anak jalanan dapat hidup tanpa bergantung dengan orang lain. (http://www.merdeka.com/jakarta/tekan-jumlah-anakjalanan-dki-bakal-perbanyak-rumah-singgah.html) . Dengan adanya berbagai macam program yang 
ada di setiap rumah singgah, diharapkan cara tesebut mampu meminimalisir anak jalanan di DKI Jakarta.

Pelaksanaan Program yang ada di berbagai rumah singgah khususnya di DKI Jakarta dilakukan oleh Satuan Bakti Pekerja Sosial (Sakti Peksos). Sebagaimana yang tertulis dalam pedoman PKSA tahun 2011, bahwa Sakti Peksos adalah :

Satuan Bakti Pekerja Sosial (SAKTI PEKSOS) merupakan petugas kemanusiaan di bidang pekerjaan sosial yang ditetapkan oleh Kementerian Sosial atau Dinas/ Instansi Sosial yang memiliki status kerja kontrak karya dengan Direktorat Kesejahteraan Sosial Anak (PKSA Pusat) atau Dinas/Instansi Sosial Provinsi (PKSA Dekon).

Melalui PKSA, Sakti Peksos ditempatkan diseluruh RPA sebagai pendamping dalam memberikan pelayanan terhadap anak jalanan untuk memenuhi kebutuhan dasarnya. Pekerja sosial dituntut untuk melakukan peran sesuai dengan kasus apa yang sedang ditanganinya, karena permasalahan yang dihadapi adalah anak jalanan maka setidaknya pekerja sosial melakukan empat peran yang mengacu pada Suharto (2011) terdiri dari peran sebagai perantara (broker roles), peran sebagai pemungkin (enabler roles), peran sebagai mediator (mediator roles) dan peran sebagai educator (educator roles).

\section{Peran Sebagai Perantara (broker roles)}

Peran sebagai perantara,pekerja sosial bertindak di antara klien atau penerima pelayanan dengan sistem sumber (bantuan materi dan non materi tentang pelayanan) yang ada di bandan/lembaga/pabti sosial. selain sebagai perantara, pekerja sosial juga berupaya membentuk jaringan kerja dengan organisasi pelayanan sosial untuk mengontrol kualitas pelayanan sosial tersebut. Peran sebagai broker muncul akibat banyaknya orang yang tidak mampu menjangkau sistem pelayanan sosial yang biasamya memiliki aturan penggunaannya yang kompleks dan kurang responsive terhadap klien atau penerima pelayanan

\section{Peran Sebagai Pemungkin (enabler role)}

Peran sebagai pemungkin adalah peran yang paling sering digunakan dalam profesi pekerjaan sosial, karena peran ini diilhami oleh konsep pemberdayaan dan difokuskan pada kemampuan, kapasitas, dan kompetensi klien atau penerima pelayanan untuk menolong dirinya sendiri. Peran sebagai pemungkin adalah tanggung jawab untuk menolong klien agar mampu menghadapi tekanan situasi (proses perubahan). Oleh sebqab itu, klien atau penerima pelayanan melakukan sesuatu dengan kemampuan yang dimilikinya dan bertanggung jawab terhadap perubahan yang terjadi pada diri dan lingkungannya. Sedangkan pekerja sosial hanya berperan membantu untuk menentukan kekuatan dan unsure yang ada di dalam diri klien sendiri termasuk untuk menghasilkan perubahan yang diinginkan atau mencapai tujuan yang dikehendaki klien.

\section{Peran Sebagai Mediator (mediator role)}

Peran sebagai penghubung akan menggunakan teknik-teknik tertentu yang disesuaikan dengan nilai-nilai yang ada. Pekerja sosial bertindak untuk mencari kesepakatan, meningkatkan rekonsiliasi berbagai pernbedaan untuk mencapai kesepakatan yang memuaskan dan untuk berintervensi pada bagian-bagian yang sedang konflik, termasuk didalamnya membicarakan segara persolan dengan cara kompromi dan persuasif.

\section{Peran Sebagai Pendidik (educator role)}

Peran pekerja sosial sebagai pendidik dapat memberikan informasi kepada anak jalanan dan mengajarkan keterampilan yang dibutuhkan. Sehingga pada pelaksanaannya pendidik dituntuk untuk berpengetahuan luas. Senlain itu, pekerja sosial juga harus menjadi komunikator yang baik sehingga informasi yang disampaikan dapat mudah diterima dengan baik pula. 


\section{Penutup}

Permasalahan sosial yang dihadapi anak jalanan antara lain, anak tidak terpenuhi hak untuk tumbuh kembang secara wajar, Anak jalanan juga sering mendapatkan perilaku salah, tindak kekerasan dan eksploitasi sehingga mempengaruhi tumbuh kembangnya sebagai anak. Dalam proses pertolongan, peran pekerja sosial sangat beragam tergantung pada konteksnya. Tugas utama pekerja sosial adalah memberikan pelayanan sosial baik kepada individu, keluarga, kelompok maupun masyarakat yang membutuhkan sesuai dengan nilai-nilai, pengetahuan dan keterampilan profesional pekerjaan sosial.

\section{Daftar Rujukan}

Irwanto, “Anak-Anak Jalanan Anak-Anak Kita Sendiri”. Jurnal Sosiologi Indonesia, No.3/1998. Ikatan Sosiologi Indonesia

Jhonson, Louise C. 1992. Social Work Practice: a general approach, 4th edition.Canada: Boston: Allyn and Bacon.

Tuti, Kartika. Anak Jalanan dan Model Penanganannya: Studi kualitatif tentang Anak Jalanan yang dibina oleh Yayasan Dian Mitra, YKAI dan Yayasan Amalia di Jakarta.

Sumber lain:

Pedoman Program Kesejahteraan Sosial Anak Tahun 2011

http://news.detik.com/read/2013/01/04/175000/2133555/10/jokowi-ngaku-belum-punya-terobosanuntuk-anak-jalanan (diakes pada 31/03/2014 10.58).

http://www.merdeka.com/jakarta/tekan-jumlah-anak-jalanan-dki-bakal-perbanyak-rumahsinggah.html (diakes pada 20/04/2014 pukul 19.25).

http://health.liputan6.com/read/2028831/terbiasa-di-jalan-anak-jalanan-tak-betah-di-rumah-singgah (diakses pada 20/04/2014 pukul 19.25) 